\title{
The Influence of Sufism Thought Shaykh Burhanuddin among the Minangkabau Community in Medan City
}

\author{
Agustianda \\ SMK IT Marinah al-Hidayah Medan \\ agustianda@yahoo.com
}

\begin{abstract}
Shaykh Burhanuddin is one of the great famous ulama from West Sumatra, who has developed Islam teachings through the Tariqa Shattariyya which spread until Medan City. Shaykh Burhanuddin developed his thinking through education at the surau. The students who studied at the Surau Shattariyyah opened to learn a whole series of Islamic knowledge. The people of Minangkabau know and practice wisdom. They are not limited to Minangkabau people in West Sumatra. Minangkabau people outside West Sumatra still regard Shaykh Burhanuddin as wali Allah and a great ulama. Shaykh Burhanuddin's teachings are continuesly developed by his students until they stay in Medan. The purpose of this research was to know the background of sufism thought by Shaykh Burhanuddin, to know the process of the Shaykh Burhanuddin's sufism thought development into Medan, and to find out why Minangkabau people in Medan follow the teachings of Shaykh Burhanuddin. This research used a descriptive qualitative approach classified to the field research to see how far the development of sufism thought Shaykh Burhanuddin among Minangkabau people in Medan. From this study, it can be concluded that the patterns of thinking influenced the background of Shaykh Burhanuddin's sufism thought was brought by the previous teacher Ahmad al-Qushashi as well as Shaykh Burhanuddin's teachers, Shaykh 'Abd al-Rauf. The idea of Shaykh Burhanuddin sufism is the three main pillars that reconcile shari'a, and sufism developed by his teacher Shaykh 'Abd al-Rauf, namely the divinity and its relationship with nature, insan al-kamil and the tarekat. In the ideas development of sufism by Shaykh Burhanuddin in Medan city, initially through the Labai and Tuangku from Ulakan, and then due to the increase and spread of Minangkabau community in several districts in Medan. The Minangkabau community in Medan
\end{abstract}


mostly follow the teachings practice of Shaykh Burhanuddin. All forms of the religious pratices are sufism 'amali activities. Sufism 'amali is sufism which emphasizes amaliyah (act) such as wirid, dhikr, and other worship.

Keywords: Sufism Thought, Shaykh Burhanuddin, Tariqa Shattariyyah, Medan City

Abstrak. Shaykh Burhanuddin adalah salah seorang ulama besar yang terkenal di Sumatera Barat yang telah mengembangkan ajaran Islam melalui ajaran Tariqa Shattariyya yang sudah sampai di kota Medan. Shaykh Burhanuddin mengembangkan pemikirannya melalui pendidikan di surau. Murid-murid yang belajar di surau Shattariyyah terbuka untuk mempelajari seluruh rangkaian pengetahuan Islam. Bahkan sebagian besar masyarakat Minang telah mengenal dan mengamalkan ajaran yang dibawanya. Tidak terbatas dengan masyarakat Minang di Sumatera Barat, masyarakat Minang yang berada di luar Sumatera Barat sampai sekarang tetap menjadikan Shaykh Burhanuddin sebagai Waliyullah dan seorang ulama besar. Ajaran Shaykh Burhanuddin terus dikembangkan oleh murid-muridnya sampai ke Medan. Adapun tujuan dari penelitian ini dilakukan adalah untuk mengetahui latar belakang pemikiran tasawuf Shaykh Burhanuddin, untuk mengetahui proses berkembangnya pemikiran tasawuf Shaykh Burhanuddin sampai ke Medan, dan untuk mengetahui Mengapa masyarakat Minang kota Medan mengikuti ajaran dari Shaykh Burhanuddin. Tesis ini menggunakan pendekatan kualitatif deskriptif yang digolongkan kepada penelitian lapangan, untuk melihat sejauh mana perkembangan pemikiran tasawuf Shaykh Burhanuddin di kalangan masyarakat Minang Kota Medan. Dari penelitian ini dapat disimpulkan bahwa latar belakang pemikiran tasawuf Shaykh Burhanuddin dipengaruhi pola pemikiran yang dibawa oleh guru sebelumnya Ahmad al-Qushashi maupun guru dari Shaykh Burhanuddin sendiri Shaykh 'Abd Rauf. Adapun pemikiran tasawuf dari Shaykh Burhanuddin adalah tiga pilar utama yang merupakan rekonsiliasi syari'ah dan tasawuf yang dikembangkan oleh gurunya Shaykh 'Abd Rauf yaitu Ketuhanan dan hubungannya dengan Alam, Insan kamil dan jalan menuju Tuhan. Dalam perkembangan pemikiran tasawuf Shaykh Burhanuddin di kota Medan yang pada awalnya melalui para Labai dan Tuangku dari Ulakan, selanjutnya karena komunitas masyarakat Minang sudah mulai bertambah banyak dan menyebar di 
beberapa kecamatan di kota Medan. Masyarakat Minang di Kota Medan sebagian besar mengikuti pengamalan ajaran dari Shaykh Burhanuddin. Segala bentuk praktek keagamaannya adalah praktik dari kegiatan tasawuf Amali. Tasawuf amali adalah tasawuf yang penekanannya pada amaliah (perbuatan) berupa wirid, zikir dan ibadah amali lainnya.

Kata Kunci: Pemikiran Tasawuf, Shaykh Burhanuddin, Tarekat Shattariyah, dan Kota Medan

\section{Introduction}

$\mathrm{M}$

inangkabau (West Sumatra) has undoubtedly contributed to the creation of Islamic scientific traditions and discourses in the Indonesian Malay world that are distinctive and endlessly inspiring researchers because of their diversity. The entry of Islam and its development in Minangkabau is parallel with the history of the growth of trading cities in the Minangkabau region. In the early seventh century or firstcentury ofHijriyah, the East Minangkabau rantau had received Islamic preaching. West Sumatra is one of regions in the archipelago that was influenced by sufism in Aceh. This can be shown by the development of sufism thoughts and orders of tarekat in this region. One of the fast-growing orders in West Sumatra, which originated in Aceh, is the Tariqa Shattariyya. The renewal movement in cultural and religious life can be a renewal movement by scholars, namely scholars who live with a strong background in Minangkabau traditional experience and then pursue Islamic spiritual knowledge from the source countries knowledge to Mecca and Medina. Other the Middle East, which was then inherited to form a chain of long and continuous history that continues into the centuries after. One of the well-known reformist scholars in West Sumatra is Shaykh Burhanuddin. Shaykh Burhanuddin has been widely known and investigated by researchers, both in literature and from reports of other European nations.

One of the main sources explaining Islamic reform's birth in Minangkabau came from the ancient Malay Arabic script. Shaykh Burhanuddin is assumed to be born in 1056 Hijiriah / 1646 AD from a Buddhist family. He came from Guguk Sikaladi Pariangan, Padang Panjang. His parents moved to Sintuak Lubuk Alung. His real name was Kanun.When he learned from Shaykh 'Abd al-Arif (Shaykh of Madinah), he was given the title Pakih Pono (Manaf, 12). His father was named Pampak, and his mother was named Nili / Puteri Cukuep. Hisfamily was farmer. As a child, Kanun worked as a livestock herder belong to his family. In his history, Kanun who later became Pakih Pono and eventually became Shaykh Burhanuddin (al-Faryani, 2001, 73). 
When he was young, Burhanuddin and his father embraced Buddhism. Later by the invitation and preaching of a Gujarati merchant who spread Islam to residents in Pekan Batang Pengawas, Burhanuddin and his father left Buddhism and converted to Islam sincerely (Amin, 2008, 304). After converting to Islam, Burhanuddin left his hometown, Sintuak, to migrate to Tapakis and studied with a ulama, Yahyuddin, or Tuanku Madinah. Following his teacher's suggestion, Burhanuddin went to Aceh to learn from Shaykh 'Abd al-Rauf al-Singkili (Putuhena, 2007, 118). Spending thirty years in Aceh, Burhanuddin finally returned to his hometown to spread Islam there. In Minangkabau, Burhanuddin set up a surau in Tanjung Medan located in an areaof approximately five hectares and was named Surau Ulakkan. The teachings and preaching of Islam brought by Burhanuddin were well followed by the Minangkabau community and the tarekat that he developed (Tariqa Shattariyya). This tarekat in Mecca was developed by Mullah Ibrahim bin Hasan al-Kurani and Ahmad al-Qushashi. These two Shaykhs were also teachers of 'Abd al-Rauf al-Singkili from Aceh. From this fact, it is clear that sufism thought in West Sumatra was influenced by the thought of sufism in Aceh. Shaykh Burhanuddin Ulakan was a student of Shaykh 'Abd al-Rauf, who was actively developing the Tariqa Shattariyya (Amin, 2008, 300).

Shaykh Burhanuddin became a famous figure in Minangkabau because of his knowledge depth and was known an important figure in the spread of Shattariyyah teachings at the end of the 17th century. From him then emerged a series of great scholars who had learned fromhim. Some of them are either spread the teachings of Shattariyyah or chose another order besides Shattariyyah. In one of the lineages of the sanad transmission from Shaykh Burhanuddin, for example, a figure,Tuangku Nan Tuo Mansiangan who became a teacher of Tuangku Nan Tuo Cangkiang Ampek Angkek, who in the end chose to develop the Tarekat Naqsyabandiyyah. Also from Tuangku Nan Tuo Cangkiang, a student named Tuangku Nan Renceh later became part of the story of the priesthood war in Minangkabau's land.

Tariqa Shattariyya, with all its peculiarities, played important role in the spread of Islam in Minangkabau land. The tarekat was more acceptable to the community and tended not to experience rejections from Minangkabau people in general. It was because of its more peaceful and gentle methods of addressing the local culture of Minangkabau. Shaykh Burhanuddin developed his thinking through education in surau. Students in the Shattariyyah Surau are open to learn the entire range of Islamic knowledge. Most of Minangkabau people have recognized and practiced the given teachings . Not limited to the Minangkabau people in West Sumatra, and the Minangkabau people outside West Sumatra until now still consider Shaykh Burhanuddin as wali Allah and a great scholar. 
Shaykh Burhanuddin continued to develop sufism thoughts by his students in Medan city. However, Shaykh Burhanuddin's sufism thought in Ulakan is the same as that is brought by his students in Medan City. Therefore, the author is interested in examining to what extent Shaykh Burhanuddin's sufism thought is developed within the Minangkabau Community of Medan City.

The research was conducted using qualitative research method that produced descriptive data. This research method aims to describe and find meaning and a deep understanding of the research problems under study based on their social background (natural setting). Case study approach was chosen in this study because it aimed to investigate phenomena in real-life contexts where the boundaries between phenomena and contexts were not visible. Multiple sources of evidence were utilized. The number of research subjects was relatively small. Thus, the research findings can not be generalized to the subjects in other issues outside the topic under study (Yin, 2009, 18). The aim is to provide a detailed description of the background, properties, and characters obtained or the object status (Nazir, 1988, 6). The location of this present research was in the surau (mosque), which is related to the practice of the teachings of Shaykh Burhanuddin. The research center was conducted at Mesjid Raya Shaykh Burhanuddin, Jalan Rawa II Gang Langgar Ujung. The research focused on the Minangkabau people, who live surrounding the Mesjid Raya Shaykh Burhanuddin area. To enable the achievement of the findings expected, the data collection was through Observation. The data were a form of sufism activities carried out by the Minangkabau community at the Mosque of Shaykh Burhanuddin. The observations were conducted in areas that followed the thoughts of Shaykh Burhanuddin in Medan. Interview was conducted through face-to-face which isdirect interviews with disciples of Shaykh Burhanuddin and jama'ah of the Tarekat of Shattariyyah. The data were taken in the interview in the form of explanations related to research yet not existed in the literature, such as the history of the development of sufism thoughts by Shaykh Burhanuddin in Medan and the practice of sufism of the Minangkabau community in Medan.Library research was conductedto help researchers trace the discussion through the existing writings about Shaykh Burhanuddin. The data obtained from this literature research were the biographies of Shaykh Burhanuddin and the Tariqa Shattariyya developed.

\section{Short Biography of Shaykh Burhanuddin}

Shaykh Burhanuddin was born with the name Pono (Suprapto, 20o9, 286289). He was born in Ulakan, Pariaman, a village near Padang Panjang. His father was Pampak Sati Karimun Merah, and his mother was Puteri Cukuik Bilangan Pandai (Samad, 2003, 19). Other source stated that Shaykh 
Burhanuddin was born on Tuesday, 17th Shafar, in 1026 Hijriyah in Guguk Sikaladi Kanagarian Pariangan, Padang Panjang (Yayasan Raudhatul Hikmah, 1993, 33). Based on these two sources, there are differences regarding the birth of Shaykh Burhanuddin. However, it can be concluded that he was considered to beborn and lived in the early 17 th century (Hakimy Dt., 1978, 40). The childhood of Shaykh Burhanuddin was no different from the childrens life in the village. Both of his parents worked as farmers. Every day Shaykh Burhanuddin (Pono) herd buffaloes and cows (Amir, 2001, 7). In his early age, Shaykh Burhanuddin had been educated by his parents with moral and manners.

When Pono wandered in the meadow, he met a person in his age:Idris Majolelo. He also has refined manners. His childhood was also not familiar with Islamic teachings because his parents and his community did not know much about it. When he was little, he and his father were Buddhists. At that time, in Nagari Tapakis, a scholar came from Aceh named Shaykh 'Abd al-Arif, who was in the same age as Shaykh 'Abd al-Rauf while studying under Shaykh Ahmad alQushashi in Medina. Shaykh 'Abd al-Arif patiently and persistently taught Islam to the children in Nagari Tapakis. However, the results were not encouraging. Children in Nagari Tapakis still adhere to their old customs and beliefs. The scholar was well-known as“Tuanku Madinah" or "Tuanku Air Sirah”. However, invitation and preaching of Shaykh "Abd al-Arif to Burhanuddin and his father caused him to leave Buddhism Thus, he converted to Islam (Amin, 2008, 304307). When he reached adulthood, Shaykh Burhanuddin began to migrate and left his hometown. Shaykh Burhanuddin studied in Aceh under the direction Shaykh 'Abd al-Rauf, an influential mufti of the Aceh Kingdom, a student and a loyal follower of the teachings of Shaykh Ahmad al-Qushashi from Medina (Amin, 2008, 304). Shaykh Burhanuddin began with his acquaintance with a fellow shepherd friend in Tapakis who came from Ulakan named Idris Majolelo. Idris' residence was in Tanjung Medan. Idris first studied under Shaykh 'Abd Arif or Shaykh Medina. Then, Idris was invited by Shaykh Burhanuddin (Pono) to get acquainted with Islam and immediately uttered the shahada sentences in front of Shaykh 'Abd al-Arif (Boestami, 1981, 12).

During his study with Shaykh Madina, he was intelligent, diligent and obedient to teachers, , and the knowledge he taught was easy to accept and put into practice. Therefore, the Shaykh of Medina was very fond of him. Then, Burhanuddin was named after Pakih Sempurna by his teacher because among his other students, only Pono had a bright heart and perfect memory (Yayasan Raudhatul Hikmah, 1993, 8). Before he passed away, Shaykh Madina advised that Burhanuddin continued his education to one of his friends in Medina, namely Shaykh 'Abd al-Rauf. who are already well-known scholars in Aceh. In his village of Sintuk, Burhanuddin secretly taught and convinced his closest friends about 
true nature of Islamic teachings. Burhanuddin then conveyed his instructions to his parents. In the end, the teachings of Islam gradually penetrated into hearts of a small part of the Sintuk community.

The preaching of Burhanuddin did not last long. Traditional leaders and tribal leaders advised him to terminate his preaching activities yetBurhanuddin insisted. As a result, people who did not like his preaching tortured his father's livestock and threatened to be expelled from thevillage. Until the deliberation, Nagari decided to kill Burhanuddin if he did not stop his da'wah. Finally, Burhanuddin went to Aceh. On his journey to Aceh, he met four young men who were in the same age as him. They became acquainted and had the same intention to study religion in Aceh from Shaykh 'Abd al-Rauf. They were Datuk Maruhun from Padang Ganting Batusangkar, Tarapangfari Kubung Tigo Baleh Solok, Muhammad Nasir from Koto Tangah Padang and Buyung Mudo from Bayang Tarusan. They arrived in Aceh, they met Shaykh 'Abd al-Rauf and conveyed their intention to study of Islam. Shaykh 'Abd al-Rauf immediately accepted and granted his prospective students' request. At the time of his return to Minangkabau, Shaykh 'Abd al-Rauf named him Burhanuddin (defender of religion). Since that time, his name officially became Burhanuddin (Djaja, 1965, 128).

Arriving in his village, Burhanuddin founded surau Shattariyyah, a traditional educational institution in Tanjung Medan, which was immediately famous as one of the centers of Islamic scholarship in Tanjung Medan. The Surau of Shaykh Burhanuddin was originally named Surau Batang Jelatang, and is now known as Surau Gadang (Yafas, 1984, 129). In Tanjung Medan, there is a plot of land belonging to Idris Majolelo, given Raja Ulakan. It was the impression Burhanuddin was carrying and beginning to carry out the sacred task of spreading Islamic teachings. The first attempt was in the Idris Majolelo family environment. The closest neighbors then followed him. Despite being challenged by the ninik mamak group and other community leaders who were worried that their influence would diminish, eventually, most of the people of Tanjung Medad embraced Islam (Boestami, 1981, 19). The way Shaykh Burhanuddin imparted Islamic teachings to the children of the land of Tanjung Medan was through gradual soft paths. He didn't want to do it hard. The way to do this is to apply one of the al-Qur'an verses that read: "là iqraha fi al-dīn" (there is no compulsion in religion). His failure in Sintuk was repaired before now after receiving the da'wah knowledge from his teacher, Shaykh 'Abd al-Rauf (Boestami, 1981, 19).

The children also conveyed this teaching of Shaykh Burhanuddin to their parents in their respective homes. Their mothers and fathers also accepted the teachings of Islam well. Finally, the state children of Tanjung Medan became 
devout followers of Islam. They pray in the congregation and are already good at reading the holy verses of the al-Qur'an. All times always, they sincerely hope mardatillah (blessing of God), they call the people to the way of Allah. Shaykh Burhanuddin with Idris Majolelo together was active in teaching and developing Islamic teachings day and night. The children were increasingly busy reciting the al-Qu'ran. His place is already packed, and it is necessary to make a special place to accommodate these students. In cooperation, a mosque was built in Tanjung Medan, which until now, we can see the four al-Qu'ran for children (Boestami, 1981, 19).

It is important to understand that through the Tariqa Shattariyya, which became the means for Shaykh Burhanuddin to preach Islam, Islamic teachings seemed more easily accepted by the Minangkabau people. Because he presented the Islamic tarekat, which prioritized the importance of spiritual quality and inner purification compared to tarekat practices and rituals in general. Thus, the name surau cannot be separated in the tradition of the tarekat in West Sumatra, especially in the Minangkabau area. Due to the surau institution's existence, which has played an important role in transmitting various Islamic sciences. It should be noted that Ahmad al-Qushashi and Ibrahim al-Kurani originally brought the Shattariyyah Order. He was a teacher from 'Abd al-Rauf who later succeeded in developing Shattariyyah in Indonesia. But before 'Abd al-Rauf, there was already a Sufi shop who was declared responsible for the Shattariyyah teachings that developed in the archipelago through his book "Tuhfät alMursalät Ila al- Rūh al-Nab̆̈, a relatively short work on wahdah al-wujūd. He is Muhammad bin Fadlullah al-Burhanpuri.

\section{Sufism Thought Shaykh Burhanuddin}

The Thought of Sufism from Shaykh Burhanuddin is the three main pillars, which are the reconciliation of sharia and Sufism which was developed by his teacher, Shaykh 'Abd al-Rauf. The three main pillars are divinity and its relationship with nature, insan kamil, and the path to God (tariqa).

1. Divinity and its relationship with nature

In understanding the essence of God's existence, Shaykh Burhanuddin adheres to the idea that the only true form is Allah. The realm of creation is his shadow form, that is, the shadow of his true being. Although the essential way (God) is different from the shadow form (nature), there are similarities between the two forms. God performs tajalli (appearances in the form of nature). God's attributes appear indirectly to humans. Shaykh Burhanuddin revealed that only Allah is the only real being, while His creation is evidence of God's existence and His power.

In this realm of visible reality, God appears to Himself (tajallī) indirectly. In 
humans, God's attributes appear directly to be perfect, and relatively the most perfect (insan kamil). Meanwhile, how the relationship between God and nature is transcendent Shaykh Burhanuddin explained before God created the universe (al-'aläm). He always thought about himself. What resulted in the creation of Nur Muhammad from Nur Muhammad was God created the archetypes (al'ayān al-thäbitāh), namely the potential of all the universe, which became the source of the outer archetype (al-'ayān khärijiyyah), namely the inner creation. concrete form (Tuanku Hasan Basry, 16/04/2016).

In the Shattariyyah manuscript also written by Shaykh 'Abd al-Rauf, it is explained that the relationship between God and nature, according to Shattariyyah's view, is explained as follows: in the beginning, this universe was created by Allah from Nur Muhammad. Before Allah created anything, he was in Allah's knowledge, which was named al-'ayān al-thābitāh. It is a shadow of God's substance. After al-thābitāh 'ayān is incarnated in al-'ayān khärijizyyah (true God who is outside), then al-'ayann khärijiyyah it is a shadow of those who own shadow (Tuanku Hasan Basry, 16/o4/2016). Shaykh Burhanuddin also concluded that although al-ayān khārijiyyah were emanations of absolute being, they were different from God Himself. The relationship between the two is like a hand and a shadow. Although the hand could not be separated from its shadow, the latter was not the same as the former. Meanwhile, to get a direct relationship with the Lord, one has to go through kasyf.

Human reason cannot possibly understand God. Kasyf is the only door that can be reached by purifying monotheism by reciting the Tariqa Shattariyyah and practicing dhikr and ibadah with one's kayfiyat (Azra, 1994, 110). This can be explained by taking several examples, including first, the parable of the person in the mirror. In the mirror, it appears that the right side is a reflection of the left side and vice versa. If the person looking in the mirror faces several mirrors, then there are several people in the mirrors, even though they all appear as a reflection of just one person. The second parable, concerning the relationship between the hand and the hand's gesture, actually the hand gesture is not the hand but the hand itself. Third, about someone named Si Ahmad, who knows Arabic letters. Before he wrote the letter on the blackboard, it remained (thabit) in his knowledge. Knowledge stands in its substance and is erased in its oneness.

Even though the essence of the Arabic letter is not the essence of Si Ahmad (even though the letters are in his knowledge): the letter remains as a letter, and Ahmad is still Ahmad. Following the argument of fā al-kullü huwa al-haqq, it means that the existence of all things is nothing but a manifestation of Him who is the Truest. The concept of thinking of Shaykh Burhanuddin is the same as the theory of emanation. Emanation, which means the emergence of something from the emitting of the emitted substance, is the same as that which emits. 
Whereas in philosophy, emanation is the process of various forms, whether direct or indirect, mental or material, originating from the being which is the source of everything, namely God, who is the cause of everything that exists. Therefore, each of these forms is apart of God.

2. Insan kamil as an ideal human figure

In the sufism discourse, the concept of insan kamil refers to the nature of creatures and their relationship with God. According to Shaykh Burhanuddin, insan kamil understanding is that if the heart is clean from the stain of the sin of lust, it will reflect the light of the essence painted on the heart. Insan kamil is a person who can watch his heart from all forms of disobedience. This is similar to the understanding of Shaykh 'Abd al-Rauf. The discussion about Kamil's people includes the following problems: a) a) Heart problems; b) b) Human events are known as al-'ayān khärijizyyah (the concept of the physical body) and al-'ayān althäbitāh (the concept of the mental body); c) c) Behavior takhalli and tajalli (Tuanku Hasan Basry, 16/o4/2016).

3. The path to God

The tendency of sharia and sufism reconciliation in Shaykh Burhanuddin is very much at all when he explains the guidance of monotheism and dhikr. Tawhid has four dignity, namely tawhìd al-uluhiyyah, tawhid al-sifät, tawhìd al$z \bar{a} t$, and tawhìd al-afa'âl. All dignity is contained in the sentence La ilāha illā Alläh. Likewise, with dhikr. Dhikr is needed as a way to guide the intuition (kashf) to meet God. The dhikr is intended to get al-mawāt al-ikhtiyāri (voluntary death), or it is also called ideational death. The knowledge that a person gets is not by affirming the path of shari'a (Samad, $5^{1-52}$ ). The thinking above concludes that Shaykh Burhanuddin is the developer of Shaykh 'Abd alRauf Aceh, who is also a liaison figure between the wujüdiyah mulhid ideology, represented by Hamzah Fansuri and Syam al-Din al-Sumatrani, and Syuhudiyah understanding represented by Nur al-Din al-Raniri. Duski Samad calls it a mystic-philosophical synthesis (Samad, 51-52.) Ibn 'Arabi and al-Ghazali. They focused on achieving ma'rifah about Allah directly without hijab through purification of the heart and the appreciation of the meaning of worship (Istadiyantha, 2007, 5). Of the total congregation of the Tariqa Shattariyyah, only a small proportion understand the teachings themselves. This is because many pilgrims only follow the teachings that have been implemented because they follow the Shaykh, who gave him understanding.

The Minangkabau people are famous for being too fanatical about the teachings they have understood for a long time. So, other religious understandings are difficult to accept because they believe in the teachings, they embrace from the understanding they know. Every human being has the potential of ma'rifat. To gain wisdom or ma'rifat, the heart $(q \bar{a} l b)$ has an 
essential function, as Ibn 'Arabi expressed in his Fușus al-Hikam: "Qālb in the view of the sufis is the place where the kashf and inspiration come. It also functions as a tool for ma'rifat and becomes a mirror that reflects (tajalli) the meanings of miraculousness" (Daradjat, 1981, 77). In the world of sufism, qālb is knowledge about nature, including the essence of ma'rifat. The $q \bar{a} l b$ who can get ma'rifat is the qālb who has been pure from humans various defects or bad morals. Besides going through the stages of maqāmat and ahwāl, to obtain ma'rifat, one must go through certain efforts, such as the following:

1. Riyadāh, often referred to as mystical exercises, is a mental exercise to get used to not doing things that pollute the soul. Riyadāh needs to be done to obtain ma'rifat knowledge obtained through continuous acts of piety or kindness. The most important thing in riyadāh is to train the soul to let go of the mirage of worldly dependencies, and then to connect with spiritual and divine realities (Daradjat, 1981, 77).

2. Tafakur is important for those who want ma'rifat because, when the soul has learned and cultivated knowledge, then thinks (contemplates) and analyzes it, the door of miraculousness will be opened for it. According to al-Ghazali, people who think correctly will become zawi al-albāb (scholars) whose heart is open so that they will receive inspiration.

3. Tazkiyat al-năfs is the process of purifying the human soul. This process of soul purification within the framework of sufism can be carried out through the takhalli and tahalli stages. Tazkiyat al-näfs is the core of tasawuf activities.

4. Dhikr Allāh. The etymology of dhikr remembers, whereas it speaks out the tongue with utterances of praise to Allah in terms of terms. The importance of dhikr to gain knowledge of ma'rifat is based on arguments about dhikr's role for the heart. Al-Ghazali in Ihy $\bar{a}^{\prime}$, explained that the human heart is like a pool in which various kinds of water flow. The influences that come to the heart sometimes come from outside, namely the senses, and sometimes from the inside, fiction, lust, amarah, and human morals or character (Daradjat, 1981, 77). Dhikr itself can only be mastered through guidance from a spiritual teacher or shaykh. A spiritual of shaykh is a person who has attained a view that awakens all realities, is not arrogant, and does not reveal the secrets of his inner thoughts to unbelievers. Dhikr activities by the Minangkabau community are always carried out in every religious activity, including: a) Friday Prayers. Usually, after the Friday prayer, it is continued with a loud recitation, and then the Khatib leads the prayer; b) Birthday of the Prophet. During the Mawlid activities, dhikr is also carried out from morning to evening; c) 3. Prayers for 40 consecutive days. This activity is 
carried out in the Mosque of Shaykh Burhanuddin for 40 days to perform prayers five times a congregation, read al-Qur'an and $d h i k r$ after prayers.

Based on the observations of the Minangkabau community in Medan with the understanding of Shaykh Burhanuddin, it was found that several religious understandings and worship services were associated with Shaykh Burhanuddin. It's as if these worship services knowledge and experiences have become their "patent right" and have been implemented and passed down from generation to generation through their teachers. Even to become labai, Tuangku, Khatib, or Imam of the Shaykh Burhanuddin mosque in Medan must get legality and recognition and allegiance from Ulakan Pariaman scholars. It will not be acknowledged by someone to be a labai, imam, or preacher until they have received approval from Ulakan.

The entire jama'ah of Shattariyyah, only a small proportion understand its teachings. This is because many pilgrims only follow the teachings that have been implemented. After all, they are following the Shaykh, who gave him understanding. The Minangkabau people are famous for being too fanatical about the teachings they have understood for a long time. So, other religious understandings are difficult to accept because they believe in the teachings, they embrace understanding they know Jama'ah Shattariyyah in Pariaman, and those in the city of Medan are very different in quantity. Jama'ah Shattariyyah in Pariaman still fully adheres to the teachings of Shaykh Burhanuddin, who had developed Islamic teachings through the Tariqa Shattariyya. However, it is different in Medan because of several things:

a. Overseas Minangkabau people no longer want to follow traditional teachings. So, there are two terms for the overseas Minangkabau people, namely the tuo and the mudo. The tuo is a group of people who still adhere to the Minangkabau customs and teachings of Shaykh Burhanuddin. Meanwhile, the mudos are people who do not understand the Minangkabau traditions and even no longer maintain their customs and do not follow the teachings of Shaykh Burhanuddin.

b. Overseas Minangkabau people who have opened their insights into understanding Islam, thus leaving old understanding.

c. Other things make the Minangkabau people abandon their understanding, such as marrying someone who does not have the same knowledge. So, one of them follows the other's understanding.

d. There was no recruitment from the jama'ah of Shattariyyah of the Minangkabau community who had lived in Medan for a long time, so their teachings were not too developed.

According to one of the jama'ah there is a need for moral improvement to become a better person seeing the current era of globalization. In the 
Shattariyyah itself, the teaching of being an ideal human being must go through 3 approaches, namely:

a. Takhalli, which is an effort to cleanse oneself from despicable qualities from both outside and inside.

b. Tahallī is the next stage after cleaning yourself; you must fill or decorate the soul by familiarizing yourself with good qualities, attitudes, and morals. This good deed must be instilled in the soul by always repenting, asceticism, patience, and others.

c. Tajallī is the last approach after takhallī and tahallī have been carried out. Tajalli is the elimination of human characteristics in a person or selfdisclosure. That is, Allah reveals Himself to His creatures.

From this approach, the Minangkabau people consider the teachings of Shaykh Burhanuddin that were brought by his students to the city of Medan make the teachings that are considered by the majority of the community to create inner peace when doing with the dhikr method, his followers consider it a path to God and can become Insan kamil. That is because some Minangkabau people in Medan still practice the Tariqa Shattariyya by carrying out the teachings of Shaykh Burhanuddin (Jama'ah Shattariyah, 14/04/2016).

\section{Conclusion}

A person's thinking is motivated by the environment's social conditions and the figures that influence his thinking. Like Shaykh Burhanuddin, his Sufism thought was influenced by the thought patterns brought by the previous teacher Ahmad al-Qushashi and Shaykh 'Abd al-Rauf. The Thought of Sufism from Shaykh Burhanuddin is the three main pillars: the reconciliation of sharia and Sufism, which was developed by his teacher, Shaykh 'Abd al-Rauf. The three main pillars are divinity and its relationship with nature, Insan kamil, and the path to God (tarekat). Shaykh Burhanuddin's thoughts are the developers of the thoughts of Shaykh 'Abd al-Rauf Aceh, who is also a liaison figure between the Wujūdiyah Mulhīd ideology, represented by Hamzah Fansuri and Syamsuddin al-Sumatrani, and Syuhudiyah ideology represented by Nuruddin al-Raniri. Iran's thought is a synthesis of the mystic-philosophical Ibn Arabi and alGhazali, which focuses on achieving ma'rifah about Allah directly without the hijab through purification of the heart and appreciation of the meaning of worship. Mistico-philosophical is a combination of philosophical Sufism and Amali Sufism. So far, the development of Sufism thoughts by Shaykh Burhanuddin has been brought by his students to Medan. The development of Shaykh Burhanuddin's teachings to the city of Medan cannot be separated from the background of the Minangkabau people who like to go overseas. Migrating for the Minangkabau is an inseparable part. Merantau has significant meaning 
for Minangkabau sons in the process of maturing self-concept and economic maturation. Minangkabau people will not grow up until they migrate to the Minangkabau Community in Medan.

Generally, the development of Shaykh Burhanuddin teachings in Medan was much lowered by the first Minangkabau people who came from the Ulakan, Tanjung Medan, Garingging River, Tiku, VII Koto, Sariak River, Limau River, Sunur, Toboh, Manggopoh, Pauh Kambar, Tapakih Katapiang, Sungai Sirah and its surroundings are known to be the base and center of Shaykh Burhanuddin in West Sumatra. Not ignorant is different from the practice of the teachings of Shaykh Burhanuddin in Ulakan, where the migrants from Padang Pariaman will develop a togetherness system as developed in the surau in the teaching complex of Shaykh Burhanuddin. In the development of Shaykh Burhanuddin in Medan, initially through Labai and Tuangku from Ulakan, the Minangkabau community has started to multiply and spread in several sub-districts in the city of Medan. In some religious activities, it is essential to have labai as leaders religious. So, it was the labai that were sent to Medan that developed the thoughts and teachings of the Shattariyyah order up to now, which Tuanku Hasan Basry did in Medan. Until now, the teachings of Shaykh Burhanuddin that his students brought to Medan are still followed by the Minangkabau people in Medan. The form of practice that is always carried out by the Minangkabau community is a form of religious practice that refers to actions that can get closer to God. The jama'ah of Tariqa Shattariyya said that the Shattariyyah are teachings that are flexible in responding to the people's religious dynamics and addressing local cultural traditions.

The teachings of Shattariyyah greatly influenced the traditions of the Minangkabau culture. The term Minangkabau people "Adaik Basandiang jo Syarak, Syarak Basandiang jo Kitabullah" (adat side by side with shara'. Shara' side by side with the book of Allah)." They do not need to leave the Minangkabau cultural tradition to implement sharia. Following the concept developed by Shaykh Burhanuddin, who made Sufism's teaching in line with shari'a (tasawuf 'amali). All forms of religious practice are practices of Amali Sufism. Amali Sufism is Sufism, which emphasizes the amaliah in the way of wirid and other amaliah. Sufism, amali or hadah, eliminates reprehensible traits, crosses all of these obstacles, and faces the total of all one's essence only to Alla SWT. In it there are principles of suluk (spiritual tarbiyah journey), various ethics (adab) in detail, such as the relationship between the student and the Shaykh, Uzlah and khalwah, not eating much, optimizing the night time, being silent, increasing dhikr, and all which is related to the principles of suluk and adab. One of Shaykh Burhanuddin thoughts that his congregation still understands to be closer to Allah is to become Insan kamil. The stages that are 
taken to become a Kamil Person are through 3 approaches, namely: takhalli, tahalli, tajalli. This approach is carried out by always making dhikr in every worship activity and applying it in everyday life. According to his congregation, the Shattariyyah teachings brought by Shaykh Burhanuddin are teachings that always emphasize efforts to achieve ma'rifah about Allah directly without hijab through purifying the heart and appreciating the meaning of worship.

\section{References}

Amin, Samsul Munir, 2008. Karomah Para Kiai. Yogyakarta: Pustaka Pesantren. Amir, Addriyetti, 20o1. Syekh Burhanuddin Ulakan, Padang: Puitika.

Azra, Azyumardi, 1994. Jaringan Ulama Timur Tengah dan Kepulauan Nusantara Abad XVIIXVIII, Bandung: Penerbit Mizan.

Boestami, 1981. Aspek Arkeologi Islam tentang Makam dan Surau Syekh Burhanuddin Ulakan, Padang: Proyek Pemugaran dan Pemeliharaan Peninggalan Sejarah dan Purbakala Sumatera Barat.

Daradjat, Zakiyah, 1981. Pengantar Ilmu Tasawuf, Medan: IAIN Sumut.

Djaja, Tamar, 1965. Pusaka Indonesia: Riwayat Hidup Orang-orang Besar Tanah Air, Jakarta: Bulan Bintang.

Faryani, Harun al-Thobahi, 2001, Sejarah Masuknya Agama Islam ke Minangkabau, Padang.

Hakimy Dt. Idrus, 1978. Rajo Penghulu, Rangkaian Mustika Adat Basandi Syarak di Minangkabau, Bandung: Rosda.

Istadiyantha, 2007. Fungsi Tarekat Syattariyah: Suatu Telaah Filologis, dalam Suntingan Teks dan Analisis Fungsi Tarekat Syattariyah, Solo: Bina Insani Press.

Manaf, Imam Maulana Abdul, tt., Sejarah Ringkas Aulia Allah Sholihin Syekh Burhanuddin Ulakan yang Mengembangkan Agama Islam di Daerah Minangkabau, Batang Kabung, Koto Tangah, Tebih, Padang: tp..

Nazir, Mohammad, 1988. Metode Penelitian, Jakarta: Ghalia Indonesia.

Putuhena, M. Saleh, 2007. Historiografi Haji Indonesia, Yogyakarta: LKiS.

Samad, Duski, 2003. Syekh Burhanuddin dan Islamisasi Minangkabau: Syarak Mandaki Adat Manurun, Jakarta: The Minangkabau Foundation.

Suprapto, Bibit, 2009. Ensiklopedi Ulama Nusantara, Jakarta: Gelegar Media Indonesia.

Yafas, M., 1984. Perkembangan Thariqat Syattariyah dan Pengaruhnya dalam Pengamalan Ajaran Islam di Kecamatan Lintau Buo, Jakarta: IAIN Imam Bonjol.

Yayasan Raudhatul Hikmah, 1993. Petunjuk Ziarah ke Maqam Syekh Burhanuddin, Jakarta: Licah Stope.

Yin, Robert K, 20o9. Case Study Research Design and Methods, terjemah M. 
Journal of Islamic Thought and Muslim Culture (JITMC), 2 (1), 2020|33

Djauzi Mudzakir, Jakarta: Raja Grafindo Persada. 